\title{
Promotion and Effective Integration of School Rooftop PV System Based Load Management Activities: A Case Study
}

\author{
Aziz Haffaf $^{1 *}$, Fatiha Lakdja ${ }^{1,2}$, Rachid Meziane ${ }^{1}$, Djaffar Ould Abdeslam $^{3}$ \\ ${ }^{1}$ Faculty of Technology, Electro-Technical Department, Electro-Technical Engineering Laboratory, Saida University, Saida \\ 20000, Algeria \\ ${ }^{2}$ ICEPS Laboratory, Djillali Liabes University of Sidi-Bel-Abbes, Sidi-Bel-Abbes 22000, Algeria \\ ${ }^{3}$ IRIMAS Laboratory, Haute Alsace University, Mulhouse 68093, France
}

Corresponding Author Email: Azzoz28@hotmail.fr

https://doi.org/10.18280/ijsdp.150410

Received: 6 January 2020

Accepted: 23 April 2020

\section{Keywords:}

decentralized generation, rooftop $P V$ system, load management, effective integration, $P V$ cells technologies, energy fed-into grid, performance ratio

\begin{abstract}
The continuing increase in energy demand, greenhouse gas emissions and negative environmental impacts associated with the use of fossil fuels has motivated researchers to find solutions to these problems. The smart grid with its components, including the rapid and significant development of dispersed generation and the Demand Side Management (DSM) concept are considered a solution to this situation. This paper aims to study the feasibility of increasing the penetration of renewable energy through the adoption of customer-side load management activities. As part of this research, the evaluation and performance analysis of a rooftop grid-connected solar photovoltaic system was carried out using pvPlanner software. A school in the province of M'sila, Algeria was selected as a case study. A comparative performance study between four different types of PV module technologies (a-Si, CdTe, CIS and $\mathrm{c}-\mathrm{Si}$ ) in terms of performance parameters according to IEC standards was conducted to determine the most appropriate solar cell technologies in this region. The effect of DSM activities on the amount of energy produced, injected into and retired from the power grid was examined. The results show that the annual average energy efficiency and performance ratio were 18.0 MWh-83.8\%, 17.5 MWh-81.1\%, 16.9 MWh-78.6\% and 16.6 MWh-77.1\%, respectively for a-Si, CdTe, CIS and c-Si technologies. Thus, amorphous silicon PV technology (a-Si) performs better than other technologies in this region. DSM leads to a decrease in energy consumption and is seen as a way to effectively promote and integrate solar energy.
\end{abstract}

\section{INTRODUCTION}

Electricity is an important factor in daily life, used to provide various applications such as lighting, energy for homes, hospitals, businesses, offices and schools and rural electrification. It has become a major concern in all countries of the world [1]. The environmental problems associated with the rapid growth in global energy demand are two related reasons and have led energy researchers to focus increasingly on the exploitation of renewable energy (RE) as it is free, sustainable and clean compared to other energy sources and conventional fuels. Among renewable energy technologies (solar, wind, etc.), solar energy is known to be used for a wide range of applications, particularly for decentralized power generation. Their advantages include quiet operation and ease of maintenance, availability, cost-effective and reliable power generation, accessibility, capacity and different sizes, especially when used in remote and isolated areas [2-4].

In terms of solar energy conversion based on the conversion of sunlight into electricity, there are two types of direct and indirect conversion: the first is the direct conversion of photovoltaic (PV) energy, and the second is achieved using the Concentrated Solar Power (CSP) system [5].

Recently, the installation rate of PV systems has increased and the number of research papers in the literature dealing with the feasibility of PV systems is on the rise. Various studies have been conducted on the analysis of the performance of PV systems at different sites around the world and under different climatic conditions, with different connection modes, using different sizes and technologies. Experimental study, actual monitoring and simulation are the most commonly used methods for the operation and analysis of PV system performance.

PV systems can be classified as grid-connected and standalone system and on small or large scale in terms of connection and size. There are many applications where PV solar energy can be used, such as stand-alone systems, water pumping, communication sites, street lighting and cathodic protection [6]. As a result of PV system applications worldwide, the annual growth rate of PV installations over the period 20102017 has reached 24\%, while the cumulative PV power output was about $415 \mathrm{GW}$ at the end of 2017 , with continuous growth [7].

An economic analysis of grid-connected rooftop PV systems for residential applications in Turkey was also been developed [8]. The design and techno-economic evaluation of a large-scale grid-connected photovoltaic system in the city of Adam, Oman, is presented by Kazem [9]. The study of a 
building-integrated photovoltaic system based on amorphous silicon (a-Si) and crystalline silicon (c-Si) is presented by Virtuani [10], where the daily performance ratio of the modules used is analyzed. Moreover, the performance of a grid-connected photovoltaic system applied at the University of Jordan has was analyzed with a payback period of 3 years [11]. Imad analyzed the results obtained from the continuous monitoring of a polycrystalline PV system with a capacity of $41 \mathrm{kWp}$ installed on the rooftop of a faculty of An-Najah National University in Palestine [4].

The objective of this research paper is to study the use of solar photovoltaic energy in schools. Therefore, many related studies available in the literature dealing with the feasibility and performance analysis of photovoltaic systems used in schools, as well as sustainable design of school buildings were reviewed. For example, a $10 \mathrm{kWp}$ monocrystalline PV system installed on the rooftop of a school in New Zealand (Wellington) was analyzed in economic and performance terms. The author notes that the school's electricity bill was significantly reduced [12]. The design of a zero-energy school in a case study in Greece and its energy performance was also analyzed [13].

Malaysian rural development policies to improve people's lives and learning conditions in rural areas rely on solar energy resources to supply electricity to schools. Thus, 160 schools were equipped with PV/diesel solar hybrid systems in the rural Sabah region [14]. Al-Otaibi [15], analyses the first gridconnected photovoltaic systems installed on the rooftops of two schools (Kuwait) over a 12-month period. The first one of $85.05 \mathrm{kWp}$ is based on thin-film PV solar cell technology and the other of $21.6 \mathrm{kWp}$ is based on copper, indium, gallium and selenium (CIGS). In another study [16], the performance evaluation and prediction of a $7.68 \mathrm{kWp}$ grid-connected PV system is examined. The PV system based on polycrystalline PV installed on the rooftop is examined for three schools in Palestine. Moreover, the application of a grid-connected PV system (si-poly) and a solar water heater for a school in Kahramanmaras (Turkey) was performed [17]. The author reports that it is possible to cover the energy needs of schools with renewable energy sources.

All these papers have made an important contribution to the literature. In many studies, grid-connected photovoltaic systems installed in schools have been analyzed in technical and economic terms, but only power production, performance ratio and capacity utilization factor have been used as parameters for evaluation and analysis. However, there are other important indicators for understanding the feasibility of photovoltaic systems, such as the quantification of the energy injected into the grid and the energy extracted from the grid as a case study, which are not addressed in most of the literature. As far as performance is concerned, PV systems under such specific conditions also depend on the technology of the PV modules used. It is therefore important to analyze several technologies in the same environment, as there is no single optimized PV technology that is unique in the world. This is one of the missing points in most of these studies, which only analyze one or two technologies. As far as the size of the PV system is concerned, it is largely related to the amount of energy consumed. This consumption can be considerably reduced because there is a great potential for energy savings in school buildings. This reduction can be achieved through the use of load management strategies and activities such as conservation strategies and the implementation of measures to improve and increase the energy efficiency of schools.
In addition, the main lack is that there is no documentation dealing with the integration of grid-connected PV systems in schools and the promotion and adoption of load management activities, i.e. the study of the effect of load management on the amount of energy consumed in schools and also its effect on the amount of energy injected into and even withdrawn from the grid. Moreover, there are no comprehensive studies dealing with the case of Algeria. Thus, this work aims to analyze and evaluate the performance of a $10 \mathrm{~kW}$ PV system on the rooftop of a school and to address most of the gaps discussed above. First, the DSM concept is discussed and some activities are considered, the effect of DSM on the energy consumed in the school and on the energy exchange profile between the grid and the school is evaluated. Next, four PV module technologies are evaluated in terms of performance to select the most appropriate one for the site. Finally, to carry out this research, a school in the province of M'sila, Algeria, was selected as a case study.

The remainder of the paper is organized as follows: Section 2 presents the DMS concept and its activities; Section 3 describes the case study and includes site information, solar resources assessment, school load data and system modeling; the design and sizing of rooftop PV systems are presented in Section 4; Section 5 describes the parameters that were used in the analysis and evaluation of the performance of the rooftop PV system; Section 6 discusses the results obtained, and finally, the various conclusions drawn from this paper are outlined in Section 7.

\section{DEMAND SIDE MANAGEMENT ACTIVITIES}

Load management as defined in the literature is the study of the load profile of consumption, the design, planning, implementation and evaluation of customer and utility activities aimed at encouraging consumers to change their behavior in terms of time and level of electricity consumption in terms of demand $(\mathrm{kW})$ and energy $(\mathrm{kWh})$ on the customer side [18]. There are two categories of DSM in utility programs The first category (energy saving or energy efficiency programs) is aimed at encouraging and motivating consumers to change their behavior to reduce energy consumption while maintaining the same service and comfort, which can be achieved by replacing less efficient equipment with less electricity-consuming appliances. The second category (load management programs), is used to reduce utility peaks to use existing resources more economically through demand shifting and load profile management [19].

As far as schools are concerned, modernization is essential on both the production and consumption sides. The development of renewable resources to provide electricity, such as solar energy, is a key element for the development and sustainability of schools. Like all the countries of the world, Algeria launched in 2011 a program for the promotion, development and integration of renewable energies, in particular photovoltaic solar energy for participation in the countries' energy mix. In 2019, the Ministry of the Interior, Local Communities and Land Management discussed the generalization of solar energy in schools, which is one of the priorities of the State, but also in various public institutions such as mosques or universities.

In terms of consumption, there is significant potential for reducing energy consumption and improving energy efficiency. In homes and schools, lighting is one of the main 
loads with very high consumption. There are several types of lamps on the market, either for indoor applications or for outdoor lighting (street, parking lot and garden lighting), such as incandescent lamps, compact fluorescent lamps (CFLs), fluorescent tubes, high-pressure sodium (HPS) technology and light-emitting diodes (LEDs). Most uses are still based on older types of energy-intensive lamps. Among these technologies, LEDs have very important characteristics in terms of energy consumption, efficiency and lifetime compared to other technologies. Their use reduces both energy consumption and electricity bill costs while maintaining the same level of comfort. Figure 1 shows a comparison of different lighting technologies [20].

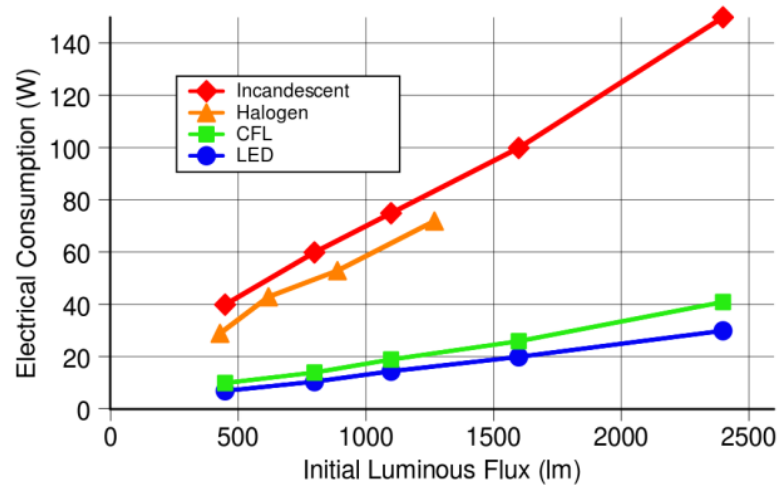

Figure 1. Efficiency comparison of residential lamps

Thus, this paper aims at the design, simulation and analysis of a project for a $10 \mathrm{kWp}$ photovoltaic system on a school' s rooftop to meet its electrical energy needs. A school from the town of M'sila, located in north-central Algeria, was selected as a case study.

The study focuses on the use of the pvPlanner software as a tool for analyzing the performance of the PV system and taking into account all parameters that influence the efficiency of the system in terms of energy production and conversion efficiency. The performance analysis and comparison of different PV module technologies based on the simulation of energy yield and performance ratio are also presented.

The second objective is the study of strategic conservation as a component of the demand management concept, to assess its effect on the integration of distributed generation in terms of energy injected into and extracted from the power grid. Next, the purpose of this paper is to define the location of the case study and assess its potential for solar resources.

A detailed assessment of energy consumption is also provided. The Solargis pvPlanner software was used to simulate and predict a $10 \mathrm{kWp}$ rooftop grid-connected rooftop solar photovoltaic system. Subsequently, an analysis of the simulation results based on the annual energy production and the performance report is presented. A determination of the best PV cells based on the results obtained is provided. Finally, the analysis of the effect of the demand management strategy on the amount of energy injected into and extracted from the power grid is performed.

\section{CASE STUDY AND ROOFTOP GRID-CONNECTED PV SYSTEM DESCRIPTION}

A $10 \mathrm{kWp} \mathrm{PV} \mathrm{system} \mathrm{is} \mathrm{proposed} \mathrm{to} \mathrm{be} \mathrm{installed} \mathrm{on} \mathrm{the}$ rooftop of a school (Bouafia Belkacem) located in a small village (Brabra) in M'sila, Algeria (35.39॰ $\mathrm{N}$ latitude and $04.54 \circ$ E longitude). Figure 2 shows a Google earth image and the location of the site on the map of Algeria. As shown in Figure 3, the proposed system consists of a PV generator, an electricity grid, a school load and an inverter. The operation of the proposed system is summarized by the fact that the excess energy of the system is injected into the electricity grid (during the day) and received from the grid (during the night).

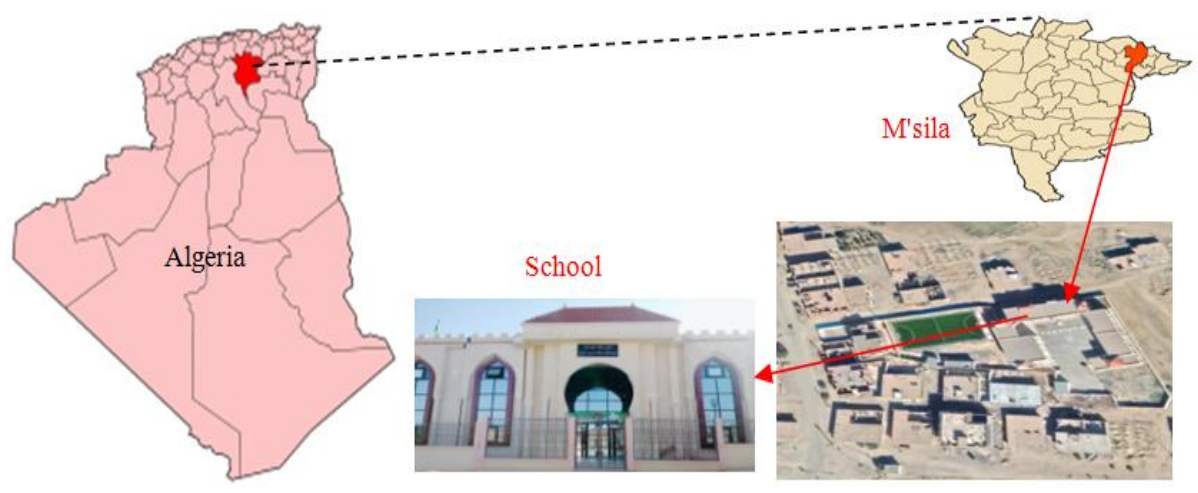

Figure 2. Location of the site and a Google earth image

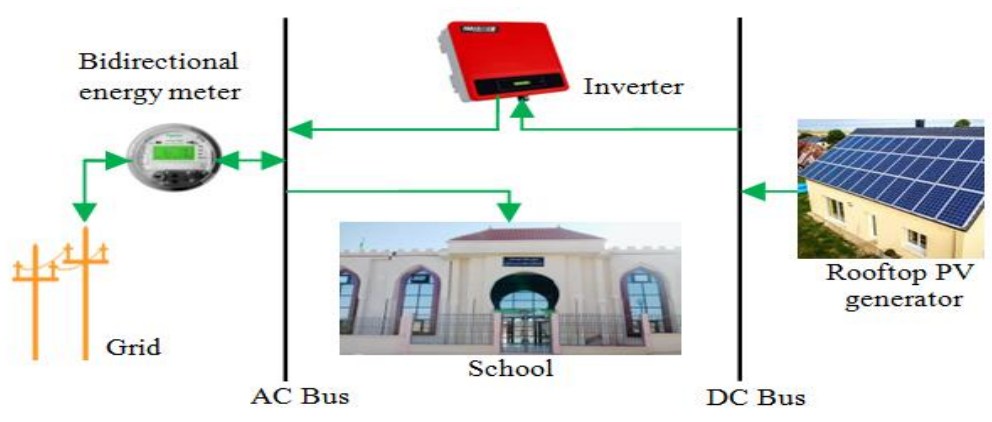

Figure 3. Diagram of the proposed rooftop grid-connected photovoltaic system 
Finally, an energy balance was carried out to determine the final direction of the energy, either from the grid to the school or from the school to the power grid.

The analysis of the technical feasibility and performance of the grid-connected PV system on the rooftop, as shown in Figure 3, was performed using the Solargis software [21].

\subsection{Solar resource assessment}

The detailed study and solar potential assessment of a given site is very important because the conversion into photovoltaic systems and its integration depend strongly on meteorological variables such as solar energy and ambient temperature with a detailed knowledge of its installation.

Figure 4(a) shows the solar radiation data of the site in terms of direct and diffuse irradiation on a monthly basis for a full year; the temperature profile is also illustrated. Figure 4(b) shows the sun's trajectory over a year for this selected area.

According to Figure 4, the maximum monthly solar irradiation value was $316.448 \mathrm{kWh} / \mathrm{m}^{2}$ in May and the minimum irradiation value was $185.4 \mathrm{kWh} / \mathrm{m}^{2}$ in December. The average solar irradiation per month was $5.04 \mathrm{kWh} / \mathrm{m}^{2} /$ day and the average ambient temperature was $22^{\circ} \mathrm{C}$.

\subsection{Load data assessment}

Following the visit to this school, it was observed that most of the equipment used is interior lighting for the design and administration offices, exterior lighting for security reasons and also some computers. Based on the analysis of the consumption of these devices, the lighting in this school was found to be inefficient and uses energy-intensive lamps such as fluorescent tubes for indoor use and high-pressure sodium (HPS) lamps for outdoor use.

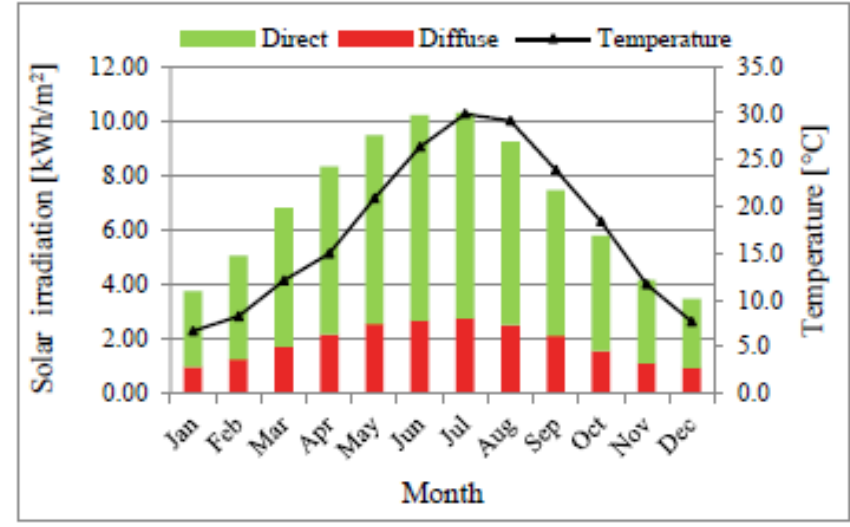

(a)

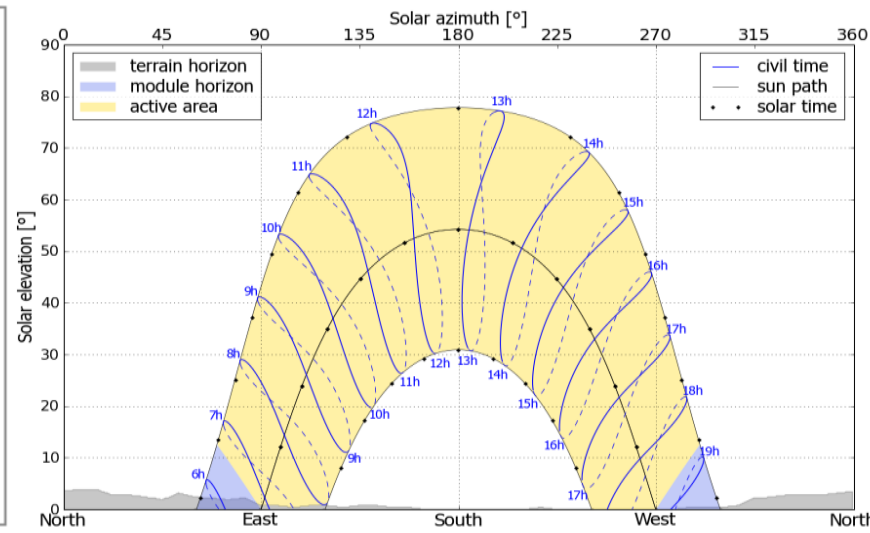

(b)

Figure 4. (a) Global horizontal irradiation and air temperature, (b) sun's trajectory over a year

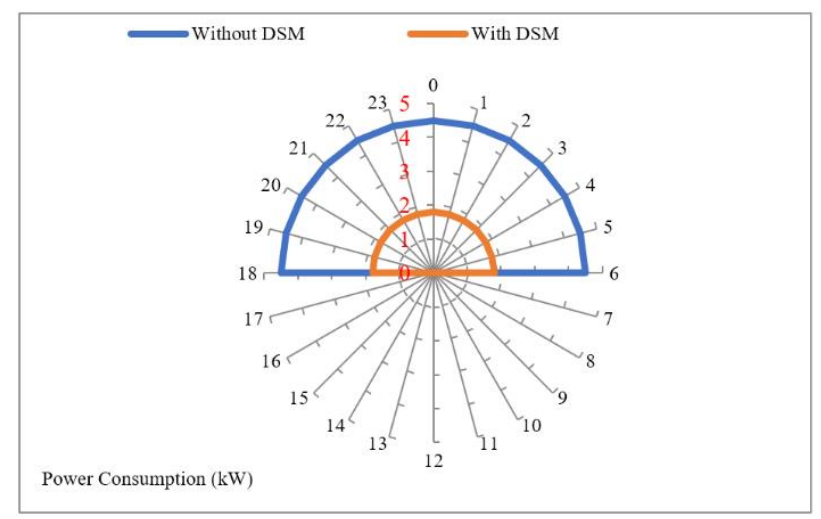

(a)

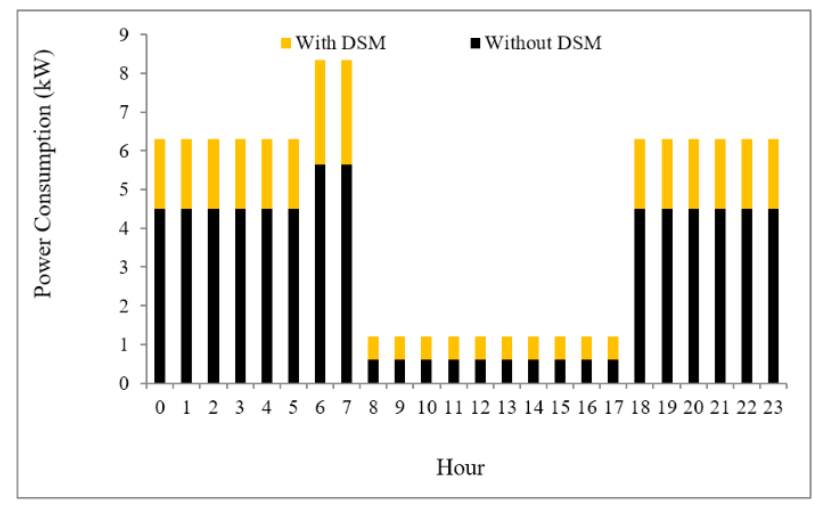

(b)

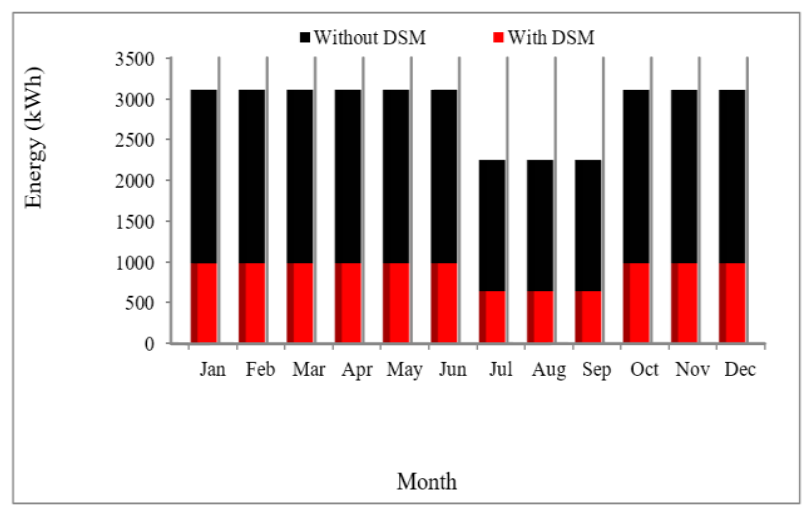

(c)

Figure 5. (a) Daily load profile: non-working day, (b) normal case: school working day, (c) monthly load profile of the selected case study

\subsection{Rooftop grid connected system modeling}

\subsubsection{PV output power}

The output power of the PV generator depends on the meteorological conditions (solar radiation and temperature), as given by Eq. (1) [22].

$$
P_{P V, \text { output }}=P_{m S T C} \times \frac{G}{G_{S T C}} \times\left(1-\gamma\left(T_{C}-25\right)\right)
$$


where, $\mathrm{P}_{\mathrm{PV} \text {, output }}$ is the calculated output power $(\mathrm{W}), \mathrm{P}_{\mathrm{m} . \mathrm{STC}}$ is the maximum rated power (W) at standard test condition (STC), $\mathrm{G}\left(\mathrm{W} / \mathrm{m}^{2}\right)$ and $\mathrm{G}_{\mathrm{STC}}\left(1000 \mathrm{~W} / \mathrm{m}^{2}\right)$ are solar radiation intensity on module and solar radiation intensity at STC, y is the power correction factor for temperature and $\mathrm{T}_{\mathrm{c}}\left({ }^{\circ} \mathrm{C}\right)$ is the PV module temperature.

\subsubsection{Inverter}

A PV system produces direct current (DC) electricity, then an inverter is used to convert the direct current from PV generators into alternating current to supply loads that are in most cases alternating [23]. The inverter efficiency can be defined as the ratio between the power supplied by the inverter in alternating form to the DC power from PV generators using Eq. (2) [24], as follows:

$$
\eta_{i n v}=\left(\frac{P_{A C}}{P_{D C}}\right) * 100 \%
$$

With regard to inverter sizing, in the case of grid-connected systems, the nominal input power of the inverter must be the same as that of the PV generator [25].

\section{ROOFTOP PV SYSTEMS DESIGN AND SIZING}

Power generation in photovoltaic systems depends on several variables and factors that must be well defined before their real installation. In this paper, the design and sizing of the rooftop PV system includes the following elements:

- PV modules sizing (panel generation factor, watt peak rating);

- Determination and optimization of the tilt and orientation angles;

- Selection of solar cell technologies:

- amorphous Silicon (a-Si);

- crystalline Silicon (c-Si);

- Cadmium Telluride (CdTe);

- Copper indium Selenide (CIS).

\subsection{PV generator sizing}

\subsubsection{Panel production factor}

The panel production factor (PPF) or panel generation factor is an element that gives for each PV panel power (Wc) an average of $\mathrm{Wh} /$ day and this varies from site to another depending on the location and climate of the site [26].

$$
P P F=\frac{\text { Daily solar radiation }}{\text { Irradiance for } P V \text { modules } S T C}
$$

\subsubsection{Energy required from PV modules}

The required energy of the PV modules is the daily required energy demand multiplied by the compensation factor for system losses as expressed in Eq. (4) [26].

$$
\mathrm{ER}=\text { Enegy demand } \times \mathrm{SLCF}
$$

where, ER (kWh) and SLCF (\%) represent the required energy from the PV modules and the loss compensation factor of the system, respectively.
4.1.3 Watt peak rating for PV modules

The total peak rating in watts of the PV modules is used and calculated by Eq. (5) to identify the photovoltaic system sizing, as follows:

$$
W P R_{(P V \text { modules })}=\frac{\text { Energy required from } P V \text { modules }}{P P F}
$$

where, PPF and WPR are the panel production factor and the watt peak rating for PV modules, respectively.

\subsubsection{Number of PV modules}

The total number of modules can be calculated based on Eq. (6):

$$
\text { Number of PV Modules }=\frac{\text { Total Watt Peak Rating }}{\text { PV Modules Peak Rated Output }}
$$

\subsection{Tilt angle and orientation}

As the production of solar energy is highly dependent on the solar irradiation potential and when they are exposed to the sun at an optimal angle. Therefore, it is very important to select the tilt and orientation angles of the PV module between the following directions (south, east, west and north) to capture the maximum amount of incident solar radiation in the collector plane, as shown in Figure 6. In this paper, the modules on the school rooftop is assumed to be mounted on a fixed structure with the following optimized parameters (tilt angle $=32^{\circ}$, azimuth angle $=180^{\circ}$ ( south $)$, albedo $\left.=20 \%\right)$.

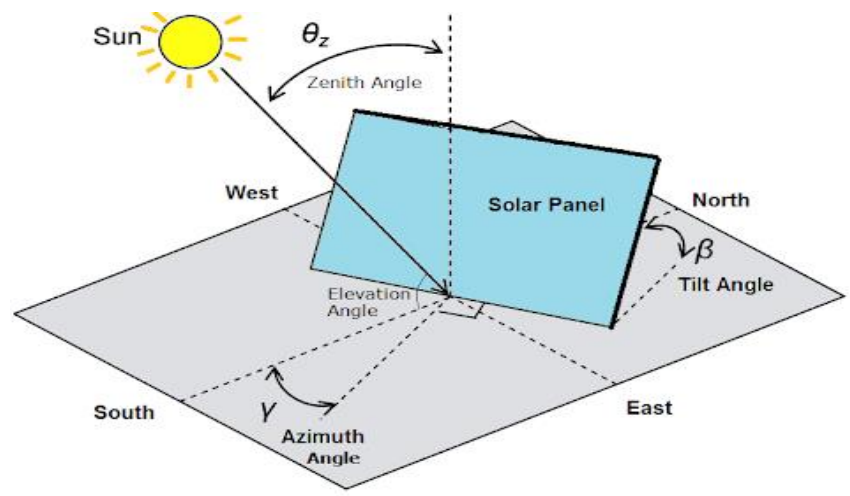

Figure 6. Orientations of PV solar module

\subsection{PV cells technologies}

The solar cell technologies used in a photovoltaic system and the meteorological data of the site have a significant influence on the PV energy output [27]. For this reason, the choice of solar cell technology is an important step in the design and simulation of photovoltaic installations. Photovoltaic technologies are classified into three generations according to the material used in their manufacture. Several solar cell technologies are available, the first generation is based on crystalline silicon (c-Si) mono-(sc-Si) or multicrystalline silicon (mc- Si) with an efficiency generally between 14 and $19 \%$.

The second generation, based on thin-film technologies, covers three main categories: 1) amorphous silicon/crystalline silicon (solar cell) (a-Si/c-Si), 2) cadmium telluride (CdTe), 3) copper-indium-gallium-selenium combination (CIS) and 
copper-indium-gallium-selenium combination (CIGS).

The third generation includes concentrated PV cells (CPV) and organic PV cells (OPV). Detailed information on the different generations in terms of efficiency and conversion is available in several studies [28, 29]. In this paper, a detailed analysis of the performance of four types of PV cells used in the proposed system in terms of energy efficiency and performance ratios was performed. The four different technologies simulated are as follows: Amorphous silicon (a$\mathrm{Si}$ ), crystalline silicon (c-Si), cadmium telluride (CdTe) and copper indium selenide (CIS).

\section{PV SYSTEM PERFORMANCE ASSESSMENT}

The performance ratio and energy efficiency according to IEC 61724 are the indices used to evaluate the overall performance of the system proposed in this paper. Figure 7 illustrates the simulation methodology used in this study.

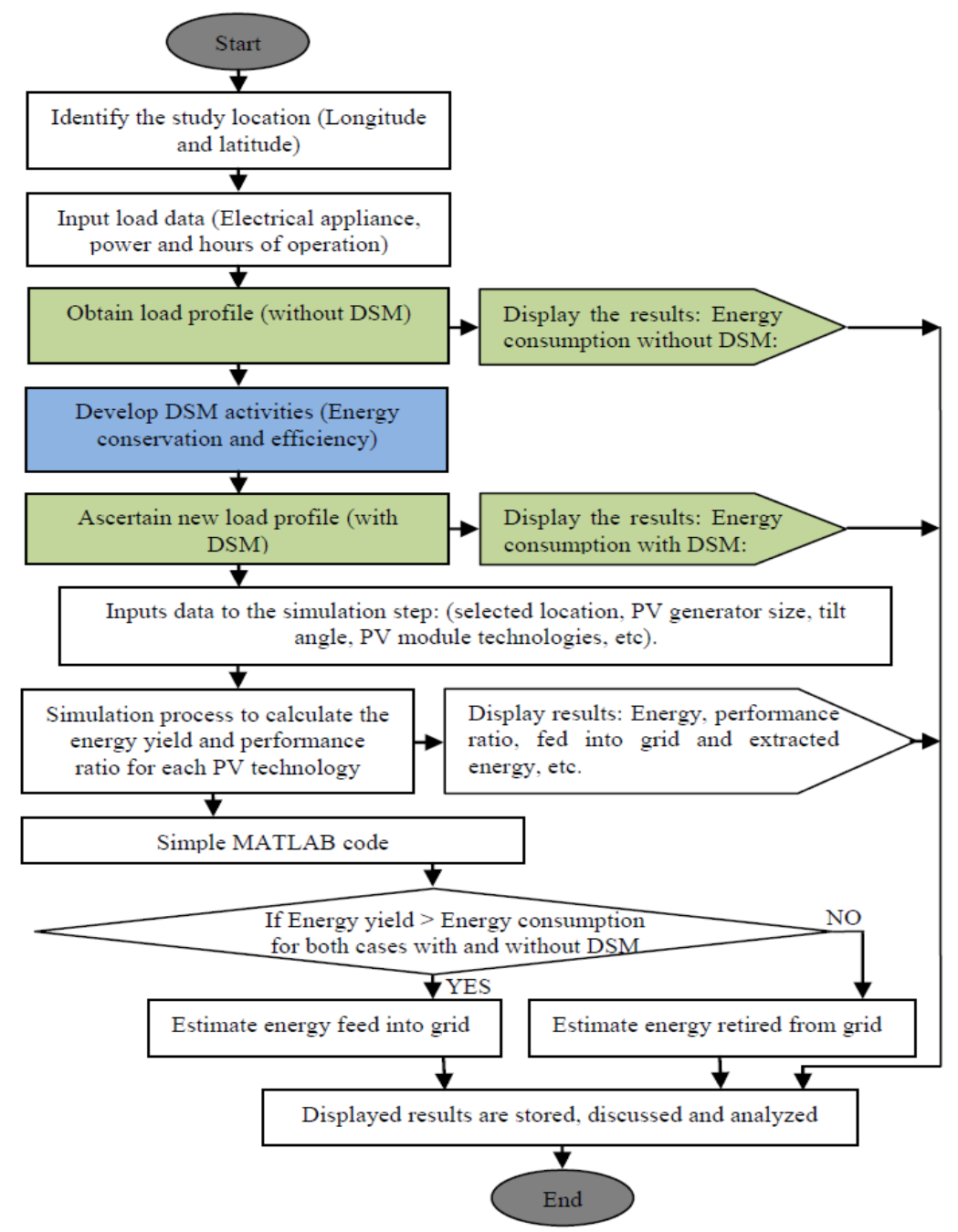

Figure 7. Proposed simulation methodology

\subsection{PV energy output}

PV energy output is the amount of energy produced by the system over a given time interval. The hourly, daily and monthly production of the system is given by Eqns. (7), (8) and (9) [30, 31], as follows:

$$
\begin{aligned}
& E_{A C, h}=\sum_{t=1}^{60} E_{A C, t} \\
& E_{A C, d}=\sum_{h=1}^{24} E_{A C, h} \\
& E_{A C, m}=\sum_{d=1}^{N} E_{A C, d}
\end{aligned}
$$

where, $\mathrm{E}_{\mathrm{AC}, \mathrm{h}}, \mathrm{E}_{\mathrm{AC}, \mathrm{d}}$ and $\mathrm{E}_{\mathrm{AC}, \mathrm{m}}(\mathrm{kWh})$ are the hourly, daily and monthly energy production, respectively; $\mathrm{N}$ is the number of days.

\subsection{Performance ratio}

The Performance ratio (PR) is a factor used for the annual analysis of system performance, defined as the ratio of final output to reference output. PRs range from 0 to 1 and their degradation indicates that there are problems in the operation of the system [32].

$$
P R=\frac{\text { Final Yield }}{\text { Reference Yield }}
$$




\subsection{Energy injected into and extracted from the grid}

Since the system under consideration is of the gridconnected type, there is in this case the possibility of an energy exchange, i.e. the import and export of energy to and from the grid. The amount of energy introduced into and withdrawn from the grid in both cases (with and without load management) is calculated by Eq. (11), as follows:

$$
\begin{gathered}
\text { Energy fed into grid/retired }=\text { Energy Yield } \\
- \text { Energy Cunsumption } \\
{\left[\begin{array}{l}
\text { Fed into grid } \rightarrow \text { if Energy Yield }>\text { Energy Consumption } \\
\text { Retired } \rightarrow \text { if Energy Consumption }<\text { Energy Y ield }
\end{array}\right]}
\end{gathered}
$$

When the energy yield is greater than the energy consumed, the result of Eq. (11) is positive, and there is an injection of energy into the power grid. Otherwise, if the result is negative, there is energy withdrawn from the grid.

\section{NUMERICAL RESULTS AND DISCUSSIONS}

This section reviews and discusses the simulation results obtained in terms of PV power generation and performance ratios for different types of PV module technologies. The effect of load management activities on the amount of energy injected and retired from the power grid on a monthly and annual basis is also examined.

\subsection{Electricity generation}

The total monthly specific energy produced by different PV cell technologies are shown in Figures 8(a) and 8(b), respectively. It should be noted that the average monthly energy production of different modules increased from January to July and decreased from July to December. Figures 8(a) and 8(b) also show that the a-Si panel system generates more energy than other technologies over the year, and their energy yields range from $111 \mathrm{kWh} / \mathrm{kWp}$ to $183 \mathrm{kWh} / \mathrm{kWp}$.

It can be observed that the energy produced by different modules was the lowest in December month due to the low solar irradiation and temperature. However, July is the month with the highest electricity production respectively for a-Si (1.8 MWh), CdTe (1.7 MWh) and 1.6 MWh for c-Si and CIS technologies.

In terms of annual and year-round energy productivity, a-Si photovoltaic technology produces the highest average annual energy output with 18.0 MWh, followed by 17.5 for CdTe, 16.9 MWh for CIS module and 16.6 MWh for c-Si technology. Figure 9 shows the percentage of monthly energy production for each PV technology.

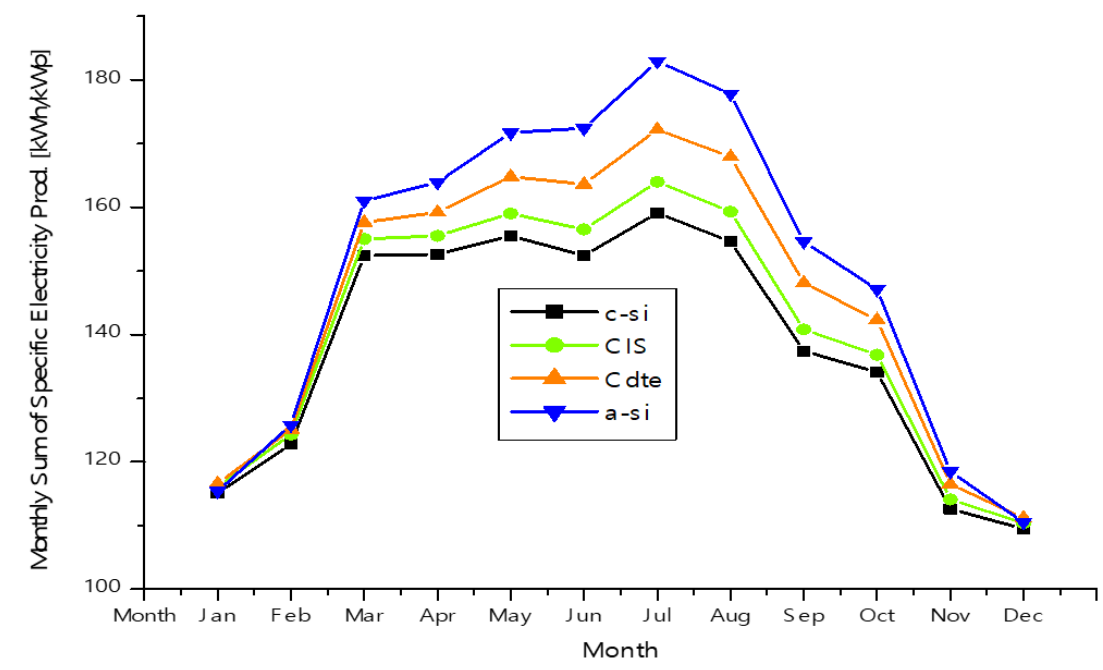

(a)

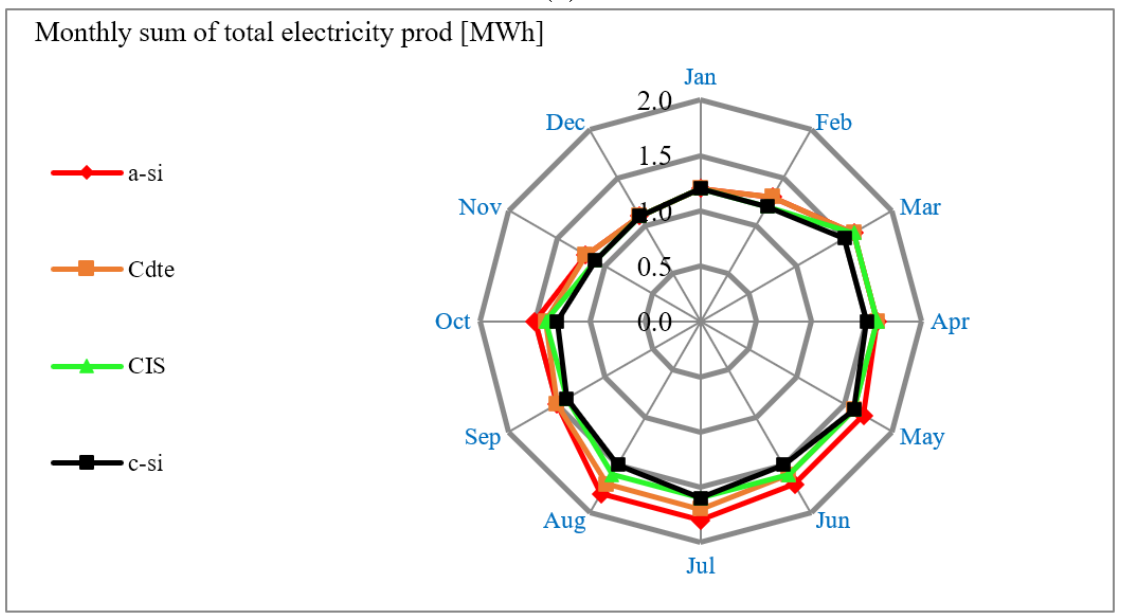

(b)

Figure 8. (a) Monthly sum of specific energy, (b) total electricity production for each PV technology 


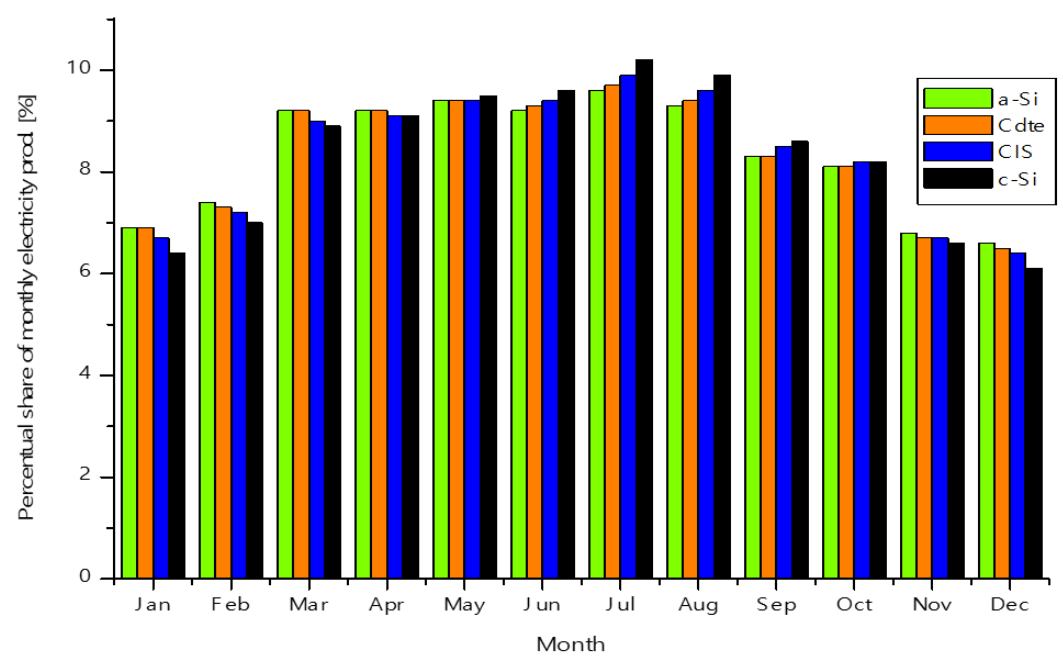

Figure 9. Share of monthly energy production for each technology

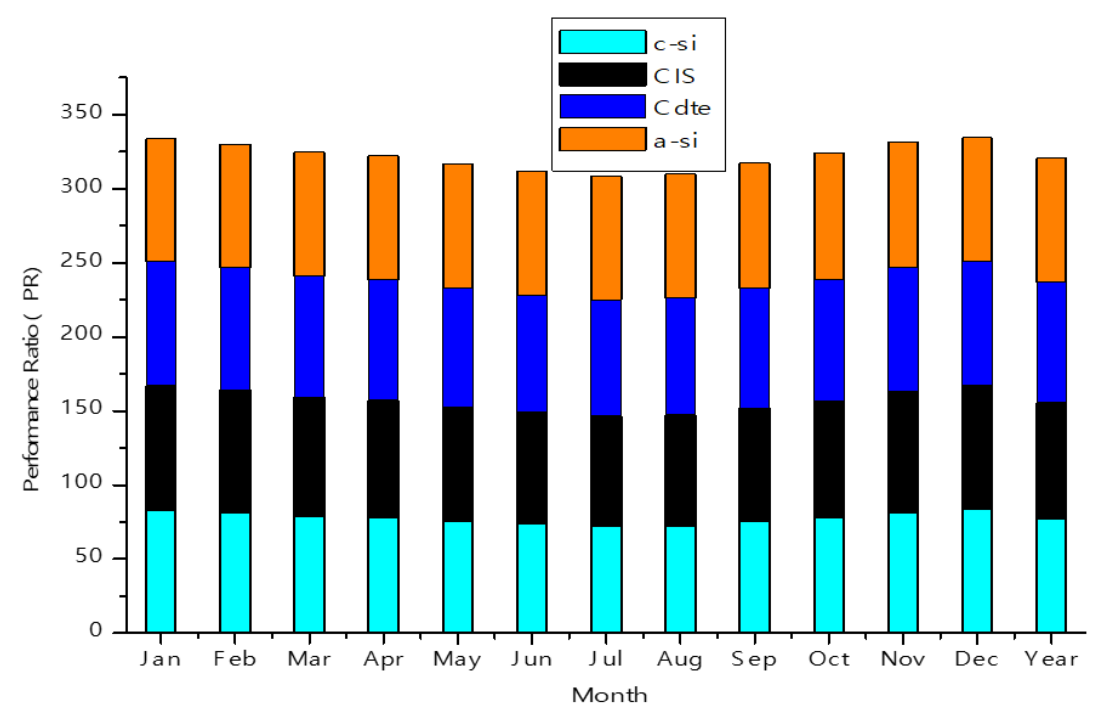

Figure 10. Performance ratio for different PV technologies

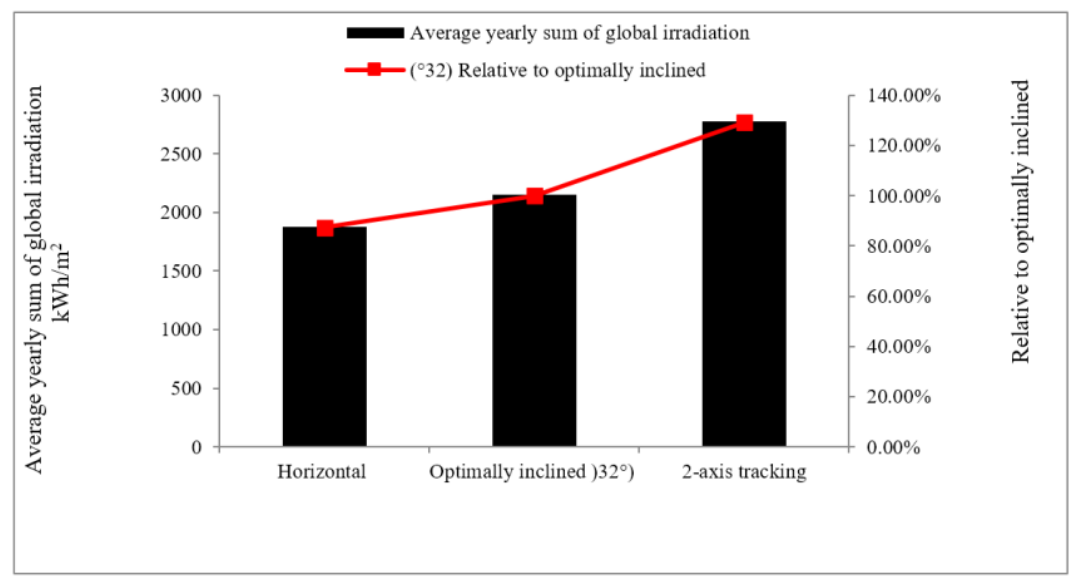

Figure 11. Average annual global irradiation for different types of surfaces

\subsection{Performance ratio analysis}

The performance of each PV system is represented by its performance ratio (PR). Figure 10 above shows the variation and the comparative analysis of the monthly performance ratio for different PV module technologies.
It should be noted that a performance ratio higher than $80 \%$ is always desirable. In this work, the PR of the system varies from $82.8 \%$ to $84.9 \%$ for (a-Si module), and from $78.4 \%$ to $84 \%$ for CdTe module, $74.4 \%$ to $83.9 \%$ for CIS module and for $\mathrm{c}-\mathrm{Si}$ it varies between $72.2 \%$ and $83.2 \%$. The a-Si PV technology has a better annual performance ratio at $83.8 \%$, 
followed by $81.1 \%, 78.6 \%$ and $77.1 \%$ for CdTe, CIS and c-Si, respectively. Thus, based on the energy yield and the PR of the individual PV modules, amorphous PV technology can be considered as the best PV technology for this site with an annual energy yield of $18.02 \mathrm{MWh} /$ year and a PR of $81.1 \%$.

\subsection{Effect of sun tracking}

Figure 11 above shows the annual global solar radiation received for the three different types of surface: horizontal surface, inclined plane and for two-axis tracker surface.

It can be observed that the two-axis system received 2774 $\mathrm{kWh} / \mathrm{m}^{2}(129.0 \%)$ followed by $1877 \mathrm{kWh} / \mathrm{m}^{2}(87.3 \%)$ compared to the optimal inclined plan with $2150 \mathrm{kWh} / \mathrm{m}^{2}$ $(100.0 \%)$, which shows the role of the solar tracking system in the installation of PV plants.

\subsection{Load management effect analysis}

The analysis of the effect of load management in terms of the amount of energy injected and extracted for different PV cell technologies was performed by comparing the two cases before and after the proposed DSM activities. Figures 12(a) and 12(b) show the energy injected into the power grid in the case where DSM is applied and the energy derived from the power grid for different solar cell technologies, respectively.

According to Figure 12(a), when load management is applied, the maximum energy injected into the grid is observed in July, followed by August and September for the a-Si technology with $1187 \mathrm{kWh}, 1136 \mathrm{kWh}$ and $904 \mathrm{kWh}$ respectively. This maximum injected energy refers to the PV production which is also maximum for these months. However, a minimum of energy injected into the grid is observed for the c-Si technology in December (111 kWh) and January (167 $\mathrm{kWh}$ ).

According to Figure 12(b), the maximum energy extracted from the power grid is observed in December with $1029 \mathrm{kWh}$ for c-Si technology (because the PV production is low), and the minimum energy extracted is for CIS technology in August $(15 \mathrm{kWh})$. It can be observed that there is no energy extracted from the power grid for the month of July when using a-Si, CdTe and CIS technologies. For the month of August, energy is retired from the power grid only in the case of c-Si and CIS technologies.

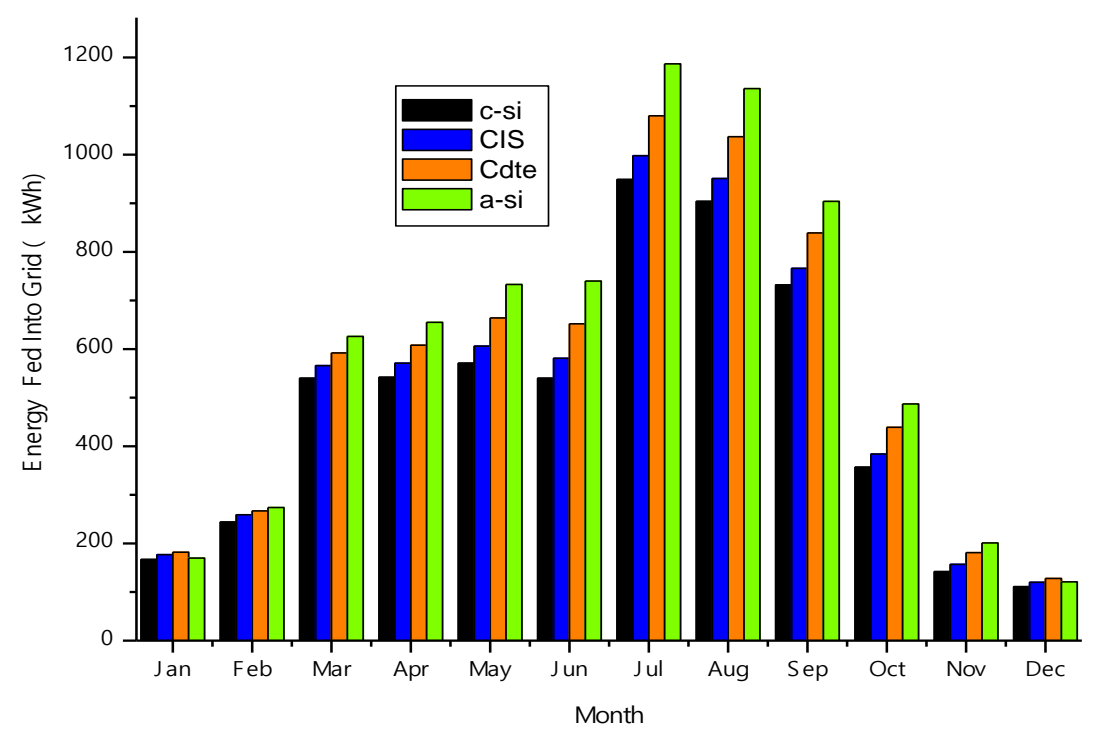

(a)

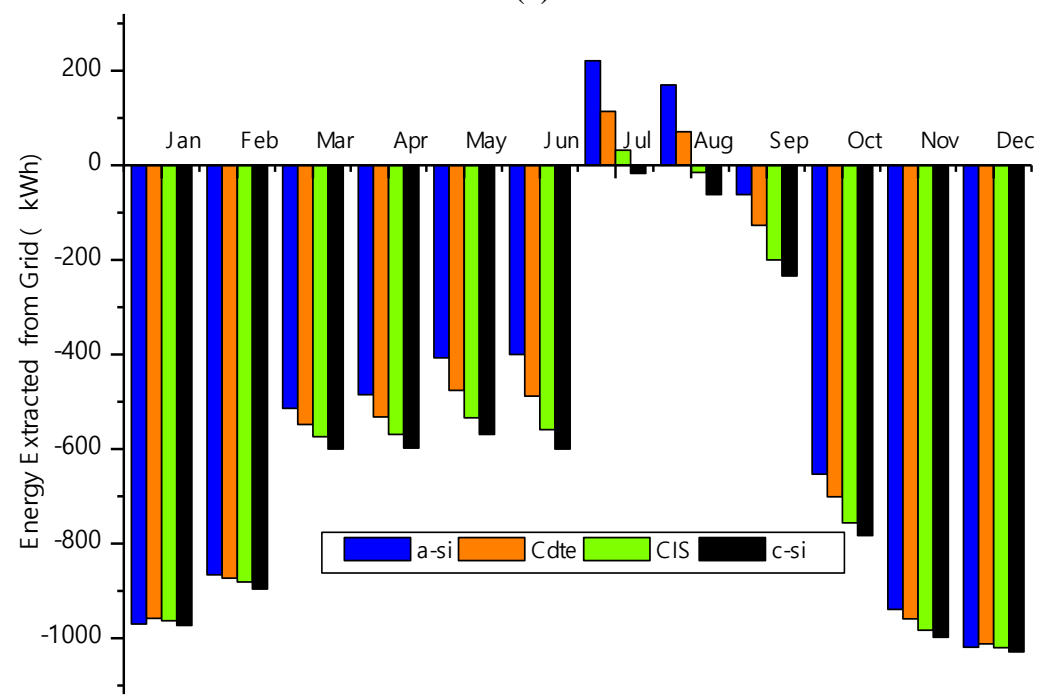

(b)

Figure 12. (a) Monthly energy fed into grid (with DSM), (b) monthly extracted energy from grid for each PV cell technology (without DSM) 


\subsection{Annual fed into grid and extracted energy}

Figure 13 shows the annual energy balance, which is the difference between the energy fed into the power grid and the derived energy for different technologies with and without load management activities. Without the case of DSM and on an annual basis, the average annual energy withdrawn from the grid was $6315 \mathrm{kWh}, 6673 \mathrm{kWh}, 7007 \mathrm{kWh}$ and $7359 \mathrm{kWh}$ for a-Si, CdTe, CIS and c-Si technologies, respectively, and there is a low level of energy injected into the power grid in this case, i.e. $391 \mathrm{kWh}$ and $185 \mathrm{kWh}$ for a-Si and CdTe, respectively. The application of load management activities eliminates the amount of energy extracted from the power grid and maximizes the energy injected, i.e. $7234 \mathrm{kWh}, 6669 \mathrm{kWh}$, $6139 \mathrm{kWh}$ and $5799 \mathrm{kWh}$ for a-Si, CdTe, CIS and c-Si technologies, respectively.

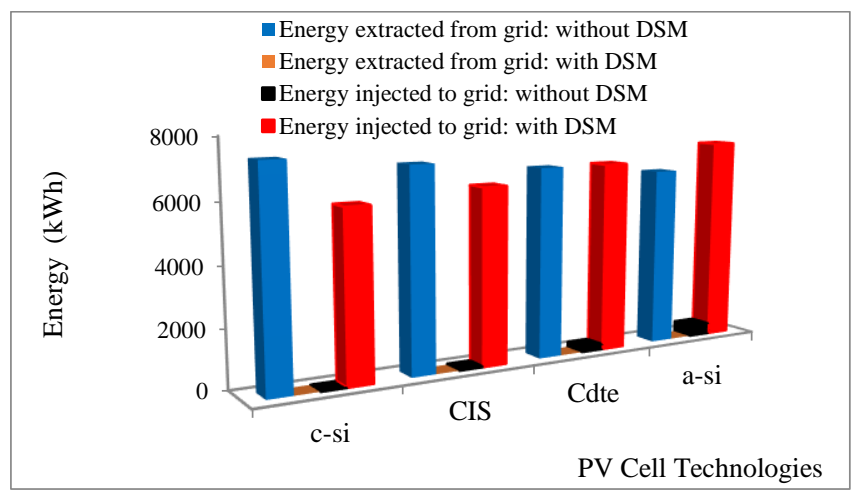

Figure 13. Energy exchange with and without DSM for each technology

\section{CONCLUSIONS}

This paper aimed to design, study and analyze the effective integration of distributed generation based on solar PV system and load management activities. The performance analysis of a proposed $10 \mathrm{kWp} \mathrm{PV} \mathrm{system} \mathrm{on} \mathrm{the} \mathrm{rooftop} \mathrm{of} \mathrm{a} \mathrm{school} \mathrm{in}$ M'sila, Algeria, was selected as a case study. Simulations were performed on the performance evaluation of four types of PV module technologies (a-Si, CdTe, CIS and c-Si) using PvPlanner software based on IEC 61724, such as energy yield and performance ratio. The effect of load management on the consumption profile of the school was examined, as well as the amount of energy fed into and out of the power grid based on monthly and annual values.

On the basis of the results obtained, it can be noted that the average annual energy yield of the a-Si module is higher than that of other technologies over the year with $1801.6 \mathrm{KWh}$. And 1745.1 KWh, 1691.8 KWh and 1658.1 KWh are the annual energy production values for a-Si, CdTe, CIS and c-Si, respectively.

The maximum average monthly performance ratio value is $83.8 \%$ for a-Si, followed by $81.1 \%$ (CdTe), $78.6 \%$ (CIS) and $77.1 \%$ (c-Si). For the amorphous silicon PV module (a-Si), it showed better performance in terms of the performance ratio and annual energy yield. The results show that the performance of grid-connected rooftop PV systems depends on the geographical location, the PV modules used and climatic data (solar irradiation and ambient temperature).

In the case of the DSM, the maximum value of the injected energy is observed for an a-Si PV panel with $1187 \mathrm{kWh}$ in July and the minimum value was $111 \mathrm{kWh}$ in December. The minimum value of the energy extracted from the grid without the DSM case is observed for the CIS PV module with approx. $15 \mathrm{kWh}$ in August and the maximum value was $1029 \mathrm{kWh}$ in September with a c-Si solar cell. Thus, as a general conclusion of this study, it can be noted that load management activities allow the promotion and high penetration of renewable energies in an efficient way, reducing large amounts of $\mathrm{CO}_{2}$ emissions and making the environment cleaner by reducing the use of fossil fuels.

\section{REFERENCES}

[1] Olugbenga, T.K., Jumah, AG.A., Phillips, D. (2013). The current and future challenges of electricity market in Nigeria in the face of deregulation process. African Journal of Engineering Research, 1(2): 33-39.

[2] Halabi, L.M., Mekhilef, S., Olatomiwa, L., Hazelton, J. (2017). Performance analysis of hybrid PV/diesel/battery system using HOMER: A case study Sabah, Malaysia. Energy Conversion and Management, 144: 322-339. http://dx.doi.org/10.1016/j.enconman.2017.04.070

[3] Al-Smairan, M.H., Alayyash, S.M., Shatnawi, R.S. (2019). Socio-economic effects of solar home systems in Jordan Badia - A case study in Rawthat Al-Bandan village, International Journal of Sustainable Development and Planning, 14(3): 191-201. http://dx.doi.org/10.2495/SDP-V14-N3-191-201

[4] Ibrik, I.H. (2020). Techno-economic assessment of ongrid solar PV system in Palestine. Cogent Engineering, 7(1):

1727131 . https://doi.org/10.1080/23311916.2020.1727131

[5] Shukla, A.K., Sudhakar, K., Baredar, P. (2016). Simulation and performance analysis of $110 \mathrm{kWp}$ gridconnected photovoltaic system for residential building in India: A comparative analysis of various PV technology. Energy Reports, 2: 82-88. http://dx.doi.org/10.1016/j.egyr.2016.04.001

[6] Alweheshi, S., Abdelali, A., Rajab, Z., Khalil, A., Mohamed, F. (2019). Photovoltaic solar energy applications in Libya: a survey. 2019 10th International Renewable Energy Congress (IREC). https://doi.org/10.1109/IREC.2019.8754527

[7] Fraunhofer ISE. Available online: https:/www.ise.fraunhofer.de/content/dam/ise/de/docu ments/publications/studies/Photovoltaics-Report.pdf, accessed on Dec. 25, 2019.

[8] Duman, A.C., Güler, Ö. (2020). Economic analysis of grid-connected residential rooftop PV systems in Turkey. Renewable Energy, 148: 697-711. https://doi.org/10.1016/j.renene.2019.10.157

[9] Kazem, H.A., Albadi, M.H., Al-Waeli, A.H.A., AlBusaidi, A.H., Chaichan, M.T. (2017). Techno economic feasibility analysis of $1 \mathrm{MW}$ photovoltaic grid connected system in Oman. Case Studies in Thermal Engineering, 10: 131-141. https://doi.org/10.1016/j.csite.2017.05.008

[10] Virtuani, A., Strepparava, D. (2017). Modelling the performance of amorphous and crystalline silicon in different typologies of building-integrated photovoltaic (BIPV) conditions. Solar Energy, 146: 113-118. https://doi.org/10.1016/j.solener.2017.02.035

[11] Ayadi, O., Al-Assad, R., Asfar, J.A. (2018). Techno economic assessment of a grid connected photovoltaic 
system for the University of Jordan. Sustainable Cities and Society, 39: 93-98. https://doi.org/10.1016/j.scs.2018.02.011

[12] Emmanuel, M., Akinyele, D., Rayudu, R. (2016). Techno-economic analysis of a $10 \mathrm{kWp}$ utility interactive photovoltaic system at Maungaraki school, Wellington, New Zealand. Energy, 120: 573-583. https://doi.org/10.1016/j.energy.2016.11.107

[13] Kolokotsa, D., Vagias, V., Fytraki, L., Oungrinis, K. (2019). Energy analysis of zero energy schools: the case study of child's asylum in Greece. Advances in Building Energy Research, 13(2): 193-204. https://doi.org/10.1080/17512549.2018.1488612

[14] Mahmud, A.M., Blanchard, R.E. (2016). Assessing a rural electrification program in Malaysia: System performance analysis on 11 solar PV-diesel hybrid systems. 2016 4th International Conference on the Development in the Renewable Energy Technology (ICDRET). https://doi.org/10.1109/ICDRET.2016.7421506

[15] Al-Otaibi, A., Al-Qattan, A., Fairouz, F., Al-Mulla, A. (2015). Performance evaluation of photovoltaic systems on Kuwaiti schools' rooftop. Energy Conversion and Management, 95: 110-119. https://doi.org/10.1016/j.enconman.2015.02.039

[16] Ibrik, I., Hashaika, F. (2019). Techno-economic impact of grid-connected rooftop solar photovoltaic system for schools in Palestine: A case study of three schools. International Journal of Energy Economics and Policy, 9(3): 291-300. https://doi.org/10.32479/ijeep.7593

[17] Yilmaz, S., Binici, H., Ozcalik, H.R. (2016). Energy supply in a green school via a photovoltaic-thermal power system. Renewable and Sustainable Energy Reviews, 57: 713-720. https://doi.org/10.1016/j.rser.2015.12.216

[18] Gellings, C.W. (2017). Evolving practice of demand-side management. Journal of Modern Power Systems and Clean Energy, 5(1): 1-9. https://doi.org/10.1007/s40565016-0252-1

[19] Abdelhay, A.S., Om, P.M. (2011). Electric distribution systems, first edition, chapter 12. demand-side management and energy efficiency. The Institute of Electrical and Electronics Engineers. Inc. Published 2011 by John Wiley \& Sons, Inc.

[20] Energy Star, https://www.energystar.gov/.

[21] Solargis, Available at https://solargis.info/pvPlanner/\#tl=Google:hybrid\&bm= satellite, accessed on Dec. 24, 2019.

[22] Atsu, D.K., Istvan, S., Istvan, F. (2019). Efficiency comparison of different photovoltaic modules. Acta Technologica Agriculturae, 1: 5-11. https://doi.org/10.2478/ata-2019-0002

[23] Naderi, M., Bahramara, S., Khayat, Y., Bevrani, H. (2017). Optimal planning in a developing industrial microgrid with sensitive loads. Energy Reports, 3: 124134. https://doi.org/10.1016/j.egyr.2017.08.004

[24] Piotrowicz, M., Maranda, W. (2013). Report on efficiency of field-installed PV inverter with focus on radiation variability. The 20th International Conference Mixed Design of Integrated Circuits and Systems MIXDES 2013, Gdynia, Poland.

[25] Tadesse, M. (2017). Design and feasibility analysis of building integrated PV (BIPV) system: Case study in Bahir Dar university lecture halls building. American Journal of Mechanical Engineering, 5(1): 24-32. https://doi.org/10.12691/ajme-5-1-5

[26] How to Design Solar PV System, http://www.leonics.com/support/article2_12j/articles2_1 2j_en.php, accessed on Dec, 25, 2019.

[27] Rahul, K. (2016). Design and assessment of solar PV plant for girls hostel (GARGI) of MNIT University, Jaipur city: A case study. Energy Reports, 2: 89-98. https://doi.org/10.1016/j.egyr.2016.05.002

[28] Ali, H., Khan, H.A. (2020). Techno-economic evaluation of two $42 \mathrm{kWp}$ polycrystalline-Si and CIS thin-film based PV rooftop systems in Pakistan. Renewable Energy, 152: 347-357. https://doi.org/10.1016/j.renene.2019.12.144

[29] Š́ly, V., Packa., J., Perný, M. (2018). Present state of solar cell technology. Electrotehnica, Electronica, Automatica (EEA), 66(3): 9-14.

[30] Romero-Fiances, I., Muñoz-Cerón, E., Espinoza-Paredes, R., Nofuentes, G., de la Casa, J. (2019). Analysis of the performance of various PV module technologies in Peru. Energies, 12(1): https://doi.org/10.3390/en12010186

186.

[31] IEC Standard 61724. (1998). Photovoltaic System Performance Monitoring Guidelines for measurement, Data Exchange and Analysis.

[32] Dagbasi, M., Bamisile, O., Adii, C. (2016). The technoeconomic comparison of solar power generation methods for Turkish Republic of North Cyprus. 2016 HONETICT. https://doi.org/10.1109/HONET.2016.7753430 